\title{
Eulogy to Professor Michele Maugeri
}

\author{
Francesco Silvestri - Kyriazis Pitilakis - Atilla Ansal
}

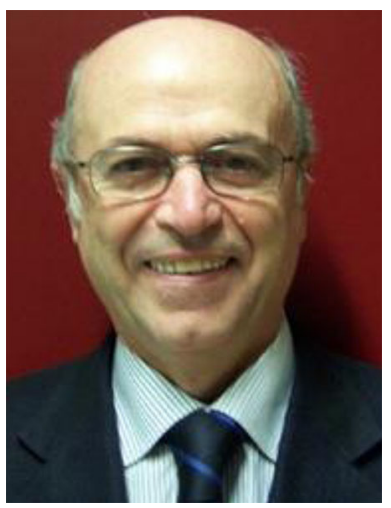

Our very dear colleague Michele Maugeri, author and Guest Editor for the Special Issue on "Performance Based Design in Earthquake Geotechnical" passed away on November 1, 2014.

He was born in Acireale (Sicily) in 1944, he got his degree in Civil Engineering from the Politecnico di Torino, winning the award for the best thesis ("Technical aspects of a bridge across the Messina Strait") and the second prize in an international competition for the fixed link road and railway between Sicily and the mainland.

His brilliant academic career developed at the University of Catania, where he was teaching since 1972, becoming Associate Professor in 1979 and then Full Professor of Geotechnical Engineering in 1990. His career was full of countless tasks of primary importance: he was a member of the Board of Public Works, member of the National Commission UNI "Construction Structural Engineering”, member of the Task Group no. 6 on "Geotechnical Earthquake Engineering and Microzonation" of the European Association for Earthquake Engineering, chairman of the "ERTC 12-Evaluation of Geotechnical Aspects of EC8". He was also active member of scientific and organizing committees of numerous national and international conferences, including the '2008 Seismic Engineering International Conference commemorating the 1908 Messina and Reggio Calabria Earthquake (MERCEA08)'.

F. Silvestri

Dipartimento di Ingegneria Civile Edile e Ambientale, Università degli Studi di Napoli “Federico II", Naples, Italy

K. Pitilakis ( $\bowtie)$

Aristotle University, Thessaloniki, Greece e-mail: pitilakis@ civil.auth.gr

A. Ansal

School of Engineering, Özyeğin University, Çekmeköy, Istanbul, Turkey 
He was the Guest Editor of several special issues of national and international journals and authored more than 300 scientific publications.

Recently, Prof. Maugeri was the Chairman of the very successful 2nd International Conference on "Performance-Based Design in Earthquake Geotechnical Engineering" held in Taormina in 2012 which led to the publication to the BEE Special Issue V12N3 and to the book on "Earthquake Geotechnical Engineering Design" V28 of the Springer book series on Geotechnical, Geological and Earthquake Engineering.

He was a scientific "ambassador" of geotechnical earthquake engineering at events organized by other international and national societies. He often focused on engineering issues relevant to Italy in the fields of seismic geotechnics, mitigation of natural hazards and geosynthetics. Through his contributions, the Italian geotechnical community has maintained a strong and beneficial dialogue with the world.

He died at his home in Sicily, just one day after he retired from University of Catania. Burial services were held on November 3 at the cathedral in his home town of Acireale. We extend our sincere sympathies and our deepest condolences to Prof. Maugeri's family and friends. He will always be remembered warmly and missed by all of us.

Ciao, Michele 